\title{
KEMAMPUAN BERPIKIR KREATIF DALAM MEMECAHKAN MASA- LAH MATEMATIKA DITINJAU DARI KEMANDIRIAN BELAJAR DI MASA PANDEMI
}

\author{
Suharsono1, Rijalush Sholikhin², Achmad B. Santoso3 ${ }^{3}$, Dian S. N. Afifah", \\ Abdul Manab ${ }^{5}$ \\ 1SMP Negeri 2 Kedungwaru \\ 1,2, 3Mahasiswa Pasca Sarjana Pendidikan Matematika, Universitas Bhinneka PGRI \\ 4,50osen Pasca Sarjana Pendidikan Matematika, Universitas Bhinneka PGRI \\ email korespondensi : suharsono10974@gmail.com
}

Diterima: (26-03-2021), Revisi: (17-06-2021), Diterbitkan: (25-06-2021)

\begin{abstract}
ABSTRAK
Tujuan penelitian ini adalah untuk mendeskripsikan kemampuan berpikir kreatif peserta didik dalam menentukan luas lingkaran ditinjau dari kemandirian belajar di masa pandemi covid-19. Pendekatan yang digunakan adalah kualitatif dengan jenis penelitian studi kasus. Subjek penelitian adalah peserta didik kelas VIII B SMP Negeri 2 Kedungwaru sebanyak 32 orang. Instrumen yang digunakan meliputi angket kemandirian belajar, soal tes dan wawancara. Analisis data dilakukan dengan reduksi data, penyajian data, dan penarikan kesimpulan. Sedangkan teknik pengecekan keabsahan data menggunakan ketekunan dalam penelitian dan triangulasi. Hasil penelitian menunjukkan peserta didik yang memiliki kemandirian tinggi memiliki kemampuan berpikir kreatif yang baik karena mampu memenuhi indikator keterampilan fluency (kelancaran), flexibility (keluwesan), originality (orisinil), dan elaboration (memperinci). Sedangkan siswa yang memiliki kemandirian sedang dan rendah memiliki kemampuan berpikir kreatif kurang karena hanya mampu memenuhi indikator keterampilan fluency (kelancaran), dan flexibility (keluwesan).
\end{abstract}

Kata kunci : Berpikir Kreatif, Kemandirian Belajar, Pandemi Covid-19 


\begin{abstract}
The purpose of this study was to describe students' creative thinking skills in determining the area of the circle in terms of independent learning during the Covid-19 pandemic. The approach used is qualitative with the type of case study research. The research subjects were 32 students of class VIII B SMP Negeri 2 Kedungwaru. The instruments used include a learning independence questionnaire, test questions and interviews. Data analysis was carried out by data reduction, data presentation, and drawing conclusions. While the technique of checking the validity of the data uses persistence in research and triangulation. The results showed that students who had high independence had good creative thinking skills because they were able to meet indicators of fluency, flexibility, originality, and elaboration. Meanwhile, students who have moderate and low independence have less creative thinking skills because they are only able to meet the indicators of fluency and flexibility skills.
\end{abstract}

Key words : Creative Thinking, Independent Learning, Covid-19 Pandemic

\title{
Pendahuluan
}

Undang-undang Nomor 20 Tahun 2003 tentang Sistem Pendidikan Nasional Pasal 1 ayat 1 telah mengamanatkan bahwa pendidikan adalah usaha sadar dan terencana untuk mewujudkan suasana belajar dan proses pembelajaran agar peserta didik secara aktif dapat mengembangkan potensi dirinya. Proses Pembelajaran diselenggarakan secara interaktif, inspiratif, menyenangkan, menantang, memotivasi peserta didik untuk berpartisipasi aktif, serta memberikan ruang yang cukup bagi prakarsa, kreatifitas, dan kemandirian sesuai dengan bakat, minat, dan perkembangan fisik serta psikologis peserta didik (Depdiknas, 2003). Dalam pembelajaran terdapat aktifitas penting yaitu interaksi edukatif antara pendidik dengan peserta didik yang didasari adanya tujuan berupa pengetahuan, sikap maupun keterampilan (Sunhaji, 2014). Secara khusus dalam penelitian ini akan dibahas tentang pembelajaran matematika.

Matematika menjadi mata pelajaran yang diajarkan pada setiap jenjang dan jenis pendidikan. Tujuan dari pembelajaran matematika adalah membekali peserta didik untuk mengembangkan kemampuan atau keahlian berpikir tingkat tinggi atau Higher Order Thinking Skill (HOTS) (Kamarullah, 2017). HOTS adalah kemampuan dalam menghubungkan, memanipulasi, dan mengubah pengetahuan serta pengalaman yang sudah dimiliki secara kritis dan kreatif dalam menentukan keputusan untuk menyelesaikan masalah pada situasi yang baru (Dinni, 2018). 
Bagian dari kemampuan berpikir tingkat tinggi atau HOTS diantaranya adalah kemampuan berpikir kritis, kreatif, logis, analitis, dan reflektif (Kusumaningrum \& Saefudin, 2012). Jadi, kemampuan berpikir kreatif termasuk dalam kemampuan berpikir tingkat tinggi.

Berpikir kreatif adalah proses berpikir untuk mengembangkan ide-ide yang tidak biasa dan menghasilkan pemikiran baru dan bermutu yang memiliki ruang lingkup yang luas dengan nengembangkan pengetahuan yang telah ada menggunakan pemikiran yang baik (Febrianti, Djahir, \& Fatimah, 2016). Pengembangan kemampuan berpikir kreatif pada pembelajaran di sekolah dititikberatkan pada keterkaitan antar unsur-unsur yang ketat, struktur, sistem, konsep dan prinsip. (Yanwar \& Fadila, 2019). Sehingga untuk meningkatkan kemampuan berpikir kreatif, peserta didik tersebut harus diberi kesempatan mengembangkan kemampuan berpikir kreatifnya. (Agustina, 2020). Kemampuan berpikir kreatif sangat mempengaruhi peserta didik dalam menyelesaikan masalah dalam kehidupan sehari-hari termasuk meneliti, memeriksa dan mengevaluasi tentang kebenaran dalam menyelesaikan masalah. Dengan kemampuan berpikir kreatif, peserta didik dapat belajar mencari akar permasalahan, mencari cara menyelesaikan masalah, mencari ide-ide penyelesaian masalah dan berusaha mengambil kesimpulan serta mendiskusikan dan mengkomunikasikan kepada teman-temannya. Peserta didik yang telah terampil dalam mengumpulkan informasi yang sesuai, mengolah dan menganalisis informasi yang diperoleh, akan dapat mengevalusi kembali dengan ide-ide yang mereka temukan.

Menurut Munandar (dalam Utami, Endaryono, \& Djuhartono, 2020) terdapat lima keterampilan dalam berpikir kreatif yaitu fluency (keterampilan berpikir lancar), flexibility (keterampilan berpikir luwes), originality (keterampilan berpikir orisinil), dan elaboration (keterampilan memperinci). Berikut akan dipaparkan pula indikator berpikir kreatif.

Tabel 1. Indikator Berpikir Kreatif

\begin{tabular}{ll}
\hline $\begin{array}{c}\text { Keterampilan Berpikir } \\
\text { Kreatif }\end{array}$ & \multicolumn{1}{c}{ Indikator } \\
\hline $\begin{array}{l}\text { Fluency (Keterampilan } \\
\text { Berpikir Lancar) }\end{array}$ & $\begin{array}{l}\text { Mampu mengungkapkan banyak pendapat, jawaban dan pe- } \\
\text { nyelesaian masalah, memberikan banyak cara dalam melaku- } \\
\end{array}$ \\
& kan berbagai hal dan selalu memikirkan lebih dari satu jawa- \\
& ban. \\
\hline
\end{tabular}




\begin{tabular}{ll}
\hline Flexibility (Keterampilan & $\begin{array}{l}\text { Mampu memberikan jawaban atau pertanyaan yang bervaria- } \\
\text { Berpikir Luwes) }\end{array}$ \\
& $\begin{array}{l}\text { si, dapat melihat suatu masalah dari sudut pandang yang } \\
\text { berbeda-beda, mencari banyak alternatif pemecahan yang } \\
\text { berbeda-beda. }\end{array}$ \\
\hline Originality (Keterampi- & Mampu menemukan gagasan baru dan unik, memikirkan cara \\
lan Berpikir Orisinil) & mengungkapkan diri dan membuat kombinasi yang tidak la- \\
& zim \\
\hline Elaboration (Keterampi- & $\begin{array}{l}\text { Mampu memperkaya dan mengembangkan suatu gagasan } \\
\text { lan Memperinci) }\end{array}$ \\
& atau produk, dan menambahkan atau memperinci secara de- \\
& tail dari suatu situasi sehingga lebih menarik \\
\hline
\end{tabular}

Perlu diketahui bahwa dipertengahan bulan Maret 2020 wabah penyakit Corona Virus Disease (Covid -19) mulai masuk ke Indonesia dan ini juga berimbas pada kegiatan belajar mengajar di sekolah. Sesuai dengan Surat Edaran Menteri Pendidikan dan Kebudayaan Republik Indonesia Nomor 4 Tahun 2020 tentang pelaksanaan kebijakan pendidikan dalam masa penyebaran Covid-19 dan dihapuskannya Ujian Nasional, untuk memutus mata rantai penyebaran Covid -19 maka proses belajar mengajar dilakukan dari rumah melalui daring/pembelajaran jarak jauh (Kemdikbud, 2020). Dengan pembelajaran daring peserta didik akan belajar sendiri dirumah sehingga terjadi keterbatasan komunikasi antara peserta didik dan pendidik. Dalam hal ini kemandirian belajar menjadi sangat penting untuk membantu berjalannya proses pembelajaran. Tentu kemandirian belajar setiap peserta didik akan berbeda-beda dalam proses pembelajaran sehingga perlu dilakukan kajian berdasarkan tingkat kemandirian belajar peserta didik.

Kemandirian belajar adalah suatu keterampilan belajar dimana semua aktivitas dan kemauan belajar dikendalikan dan dinilai oleh dirinya sendiri. Dengan demikian peserta didik dalam belajarnya akan mengaktifkan kemampuan afektif, kemampuan kognitif dan kemampuan psikomotorik yang ada pada dirinya untuk mencapai tujuan pembelajaran yang diinginkan (Jumaisyaroh, Napitupulu, \& Hasratuddin, 2015). Kemandirian belajar dapat diukur melalui beberapa indikator, diantaranya : 1) adanya inisiatif belajar; 2) mampu mendiagnosa kebutuhan belajar; 3) dapat menetapkan target dan tujuan belajar; 4) mampu mengontrol, memonitor dan mengukur kemajuan belajar; 5) memandang kesulitan belajar sebagai tantangan; 6) dapat memanfaatkan berbagai sumber belajar; 7) dapat memilih strategi belajar; 8) dapat mengevaluasi proses dan hasil belajar; serta 9) memiliki konsep diri (Jumaisyaroh et al., 2015) 
Berdasarkan hasil observasi yang dilakukan di SMP Negeri 2 Kedungwaru pada peserta didik kelas VIII B menunjukkan bahwa banyak peserta didik yang belum maksimal kemampuan berpikir kreatif penyelesaian masalah matematika pada materi geometri, khususnya dalam menentukan luas lingkaran. Hal ini dapat diketahui dari rata-rata peserta didik yang hanya mampu menyelesaikan masalah dengan menggunakan satu cara saja. Hasil penelitian Firdausi, Asikin, \& Wuryanto (2018) menunjukkan bahwa kemampuan berpikir kreatif belum optimal karena peserta didik merasa kesulitan dalam menyelesaikan masalah matematika yang lebih kompleks. Sedangkan hasil penelitian Putri, Munzir, \& Abidin (2019) menunjukkan bahwa mayoritas peserta didik belum mampu menyelesaikan soal yang memerlukan kemampuan berpikir kreatif dalam penyelesaiannya dan kemandirian belajar peserta didik cenderung rendah.

Berdasarkan pemaparan di atas maka sangat perlu dilakukan penelitian tentang kemampuan berpikir kreatif peserta didik dalam menyelesaikan masalah matematika khususnya pada materi lingkaran. Materi lingkaran digunakan sebagai acuan karena memuat kompetensi menentukan keliling dan luas lingkaran, serta memecahkan masalah yang berkaitan dengan lingkaran. Khususnya dalam penentuan luas, jika diberikan beberapa lingkaran maka penyelesaian peserta didik dapat dilakukan dengan cara yang berbeda-beda. Penelitian ini berbeda dengan penelitian sebelumnya karena peserta didik yang diteliti kemampuan berpikir kreatifnya ditinjau berdasarkan tingkat kemandirian belajar. Karena dalam kondisi pandemi covid-19 kegiatan belajar mengajar dilakukan secara daring sehingga peserta didik melakukan kegiatan belajar di rumah.

\section{Metode Penelitian}

Pada penelitian ini digunakan pendekatan kualitatif dengan jenis studi kasus, karena membahas tentang kemampuan berpikir kreatif peserta didik dalam menentukan luas lingkaran ditinjau dari kemandirian belajar. Subjek penelitian ini adalah peserta didik kelas VIII B SMP Negeri 2 Kedungwaru sebanyak 32 orang. Instrumen yang digunakan meliputi angket kemandirian belajar untuk mengetahui tingkatan kemandirian belajar peserta didik, soal tes materi geometri untuk mengetahui kemampuan berpikir kreatif peserta didik dalam menyelesaikan soal tersebut dan wawancara untuk mengetahui informasi lebih mendalam mengenai kemam- 
puan berpikir kreatif peserta didik.

Menurut Miles dan Huberman terdapat tiga tahap teknik analisis data dalam penelitian kualitatif. Tahap pertama dalam mereduksi data adalah mengkategorikan peserta didik sesuai dengan tingkat kemandirian belajar berdasarkan angket yang telah diisi, kemudian ditentukan satu peserta didik dari tiap kategori kemandirian belajar tinggi, rendah, dan sedang untuk diberikan tes. Setelah mengerjakan tes, peserta didik diwawancarai untuk menambah informasi mengenai kemampuan berpikir kreatifnya. Tahap kedua adalah menyajikan data, yaitu menampilkan hasil dan pembahasan penelitian yang telah diperoleh dari tahap reduksi data. Tahap ketiga adalah penarikan kesimpulan, yaitu menyimpulkan hasil dan pembahasan terkait dalam penelitian ini. Untuk pengecekan keabsahan data digunakan ketekunan pengamatan dan triangulasi.

Penentuan tingkat kemandirian belajar dilakukan dengan menggunakan rumus berikut.

Tabel 2. Cara Menentukan Tingkat Kemandirian Belajar

\begin{tabular}{cc}
\hline Tingkat & Rumus Interval \\
\hline Tinggi & $X \geq \mu+\sigma$ \\
\hline Sedang & $\mu-\sigma \leq X<\mu+\sigma$ \\
\hline Rendah & $X<\mu-\sigma$ \\
\hline
\end{tabular}

Keterangan :

$\mu$ : rata-rata

$\sigma:$ Standar Deviasi

\section{Hasil dan Pembahasan}

\section{Kemandirian Peserta didik}

Berdasarkan hasil penelitian diperoleh tingkatan kemandirian belajar dengan rata-rata sebesar 70,6 dan standar deviasi sebesar 20,3. Adapun kategori tingkat kemandirian belajar dapat dilihat pada tabel berikut.

Tabel 3.Tingkat Kemandirian Belajar

\begin{tabular}{ccc}
\hline Tingkat & Interval & Jumlah Peserta didik \\
\hline Tinggi & $X \geq 90,9$ & 7 \\
\hline Sedang & $50,3 \leq X<90,9$ & 15 \\
\hline Rendah & $X<50,3$ & 10 \\
\hline
\end{tabular}

Dari tabel diatas diperoleh informasi bahwa kemandirian belajar peserta didik ke- 
las VIII B paling banyak berada pada tingkat kemandirian sedang. Hal ini dikarenakan sejak bulan Maret 2020 pembelajaran diganti pembelajaran dari rumah dengan menggunakan metode daring/pembelajaran jarak jauh. Hal ini menjadi pengalaman baru bagi pendidik dan peserta didik. Pendidik dan peserta didik pun dengan persiapan yang kurang harus melaksanakan kegiatan pembelajaran daring sehingga pendidik menggunakan aplikasi WhatsApp diawal pembelajarannya melalui pemberian tugas mengerjakan Lembar Kerja Peserta Didik (LKPD) yang telah dimiliki peserta didik.

Dengan keterbatasan tersebut peserta didik dituntut untuk belajar mengerjakan tugas yang ada di LKPD secara mandiri tanpa adanya interaksi pembelajaran dengan pendidik. Peserta didik harus berusaha memecahkan permasalahan yang ada di LKPD tersebut melalui penggalian informasi dengan memanfaatkan buku paket yang ada dan mencari informasi diinternet baik berupa materi pembelajaran maupun video pembelajaran. Peserta didik berusaha untuk memahami materi di LKPD dengan berusaha mendengarkan dan melihat video pembelajaran, serta berusaha mengerjakan latihan soal. Setelah selesai peserta didik mencocokan hasil pengerjaannya dengan pembahasan yang ada pada video pembelajaran atau pada materi yang diperoleh dari internet maupun buku pelajaran. Jika materi masih belum dipahami, maka peserta didik harus terus berusaha mencari informasi dengan bertanya kepada teman atau pendidik melalui aplikasi WhatsApp. Setelah LKPD selesai dikerjakan, dilakukan diskusi hasil pekerjaan antar peserta didik dalam satu grup WhatsApp yang selanjutnya dikumpulkan ke pendidik. Peserta didik saling berdiskusi dan saling mengoreksi pekerjaan yang telah dilakukan. Jika ada pekerjaan yang tidak sama maka akan terjadi adu argumen dengan menunjukkan sumber belajar yang diperoleh dan saling menjelaskan hingga diperoleh kesepahaman.

Dalam praktek pelaksanaan belajar dari rumah tersebut sekolah membuat jadwal pembelajaran mulai pukul 07.30 hingga 11.30. Namun pada kenyataannya peserta didik melakukan pembelajaran melebihi jadwal yang telah ditentukan. Hal ini dikarenakan peserta didik berusaha untuk memahami dan menyelesaikan tugas-tugas yang ada di LKPD secara optimal. Selain itu peserta didik juga membutuhkan waktu untuk mencari literatur serta berdiskusi dengan teman-teman dalam grup belajarnya.

Dari uraian diatas menunjukkan bahwa peserta didik sudah memiliki inisiatif 
untuk belajar; sudah berusaha mendiagnosa kebutuhan belajar dan menetapkan target dan tujuan belajar; mampu mengontrol, memonitor dan mengukur kemajuan belajar; memandang kesulitan belajar sebagai tantangan; dapat memanfaatkan berbagai sumber belajar; dapat memilih strategi belajar; dapat mengevaluasi proses dan hasil belajar; serta memiliki konsep diri. Sesuai dengan indikator kemandirian belajar yang disampaikan oleh Jumaisyaroh, Napitupulu and Hasratuddin maka peserta didik tersebut dapat dikatakan sudah memiliki kemandirian belajar (Jumaisyaroh et al., 2015).

Setelah diperoleh data mengenai tingkat kemandirian belajar peserta didik, ditentukan 1 peserta didik dari tiap kategori tinggi rendah, dan sedang untuk dijadikan subjek penelitian. Dari 3 peserta didik yang menjadi subjek penelitian diberikan tes dalam bentuk soal uraian materi geometri untuk melihat kemampuan berpikir kreatifnya. Soal tes ditentukan sebagai : "Pada gambar di bawah ini luas daerah yang tidak diarsir adalah $98 \mathrm{~cm}^{2}$. Berikan beberapa penyelesaian untuk menghitung luas daerah yang tidak diarsir tersebut!".

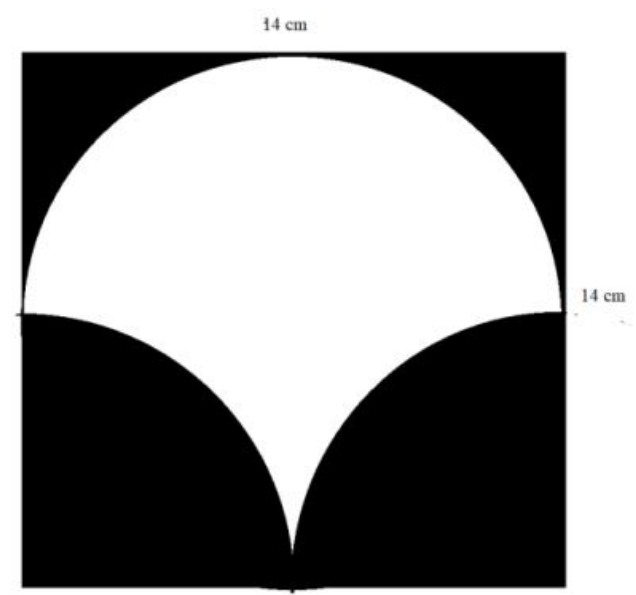

Gambar 1. Soal

\section{Jawaban Subjek dengan Tingkat Kemandirian Belajar Tinggi}

Subjek dengan tingkat kemandirian belajar tinggi memiliki kemampuan berpikir berpikir kreatif yang sangat baik. Subjek mampu memenuhi semua indikator berpikir kreatif, yaitu keterampilan kelancaran (fluency), keluwesan (flexibility), keorisinilan (originality), dan memperinci (elaboration) yang sangat baik dalam meyelesaikan soal dengan memberikan dua cara penyelesaian.

Cara pertama merupakan cara yang umum digunakan dengan menggunakan rumus yang panjang, sedangkan cara yang kedua dengan memanipulasi gambar 
agar diperoleh rumus yang lebih sederhana. Berikut hasil jawaban subjek dengan tingkat kemandirian belajar tinggi.

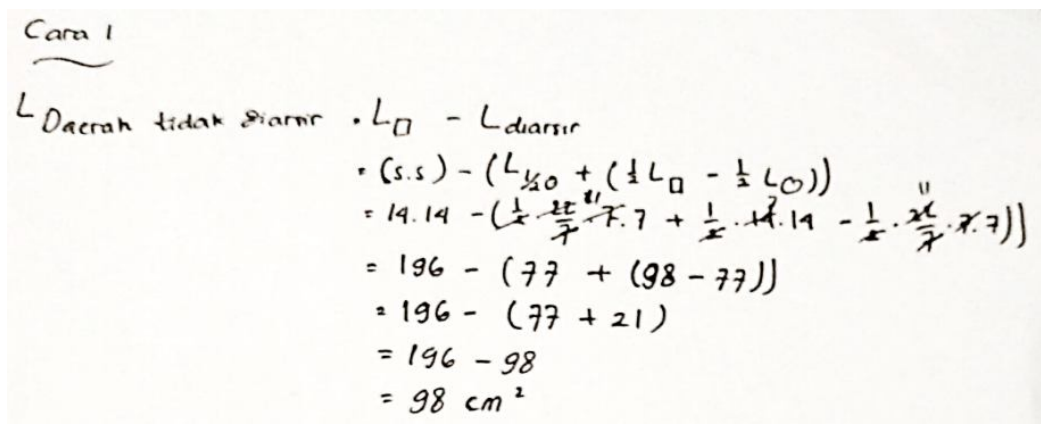

Gambar 2. Jawaban Subjek Dengan Tingkat Kemandirian Belajar Tinggi

Gambar 2 merupakan cara pertama subjek dalam menyelesaikan soal. Berdasarkan hasil wawancara subjek mampu memahami soal dengan menentukan luas daerah yang tidak diarsir dan menjelaskan cara menyelesaikan soal mulai dari menentukan luas persegi, dikurangi luas setengah lingkaran, ditambah luas setengah persegi, kemudian dikurangi luas setengah lingkaran. Hal ini menunjukkan bahwa subjek tingkat tinggi memiliki keterampilan berpikir lancar (fluency) yang baik karena mampu memberikan jawaban secara benar.

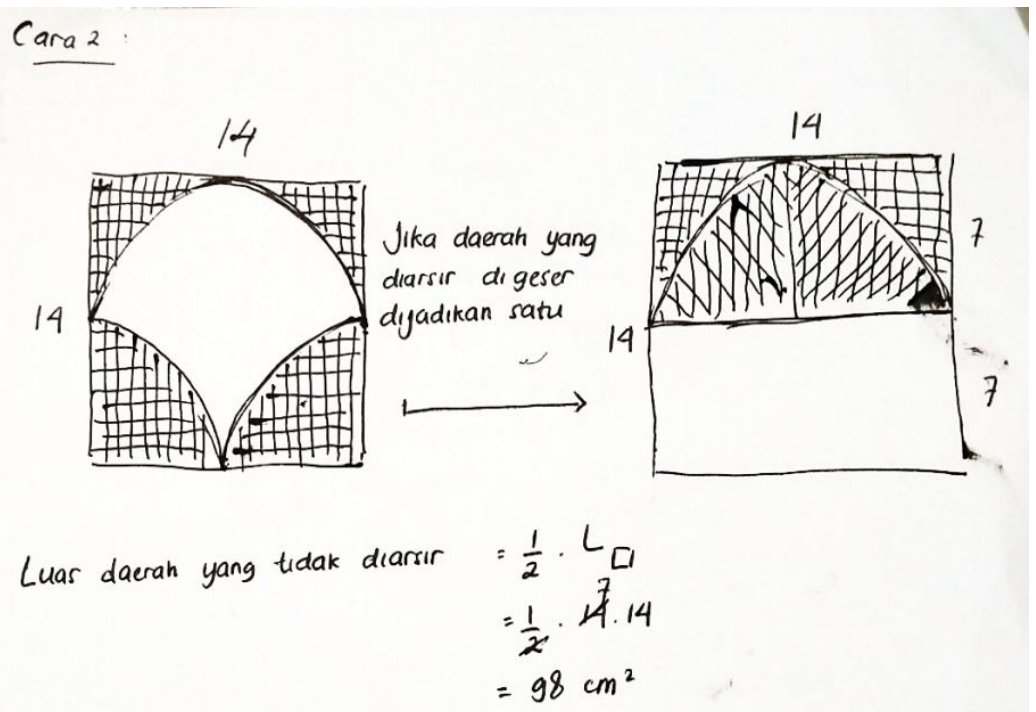

Gambar 3. Alternatif Jawaban Subjek Dengan Tingkat Kemandirian Belajar Tinggi

Berdasarkan hasil wawancara diketahui juga bahwa subjek mampu menyebutkan cara lain untuk menyelesaikan soal tersebut. Sehingga subjek dikatakan 
memiliki keterampilan berpikir luwes (flexibility) yang baik karena mampu melihat permasalahan dari sudut pandang yang berbeda sehingga menemukan alternatif pemecahan yang berbeda, seperti pada gambar berikut.

Hasil wawancara juga menunjukkan bahwa subjek menyelesaikan cara pertama sesuai teori, yaitu luas yang tidak diarsir sama dengan luas persegi dikurangi luas yang diarsir. Sedangkan pada cara kedua, subjek berusaha mengkonstruksi gambar dengan memotong persegi menjadi 4 bagian yang sama, selanjutnya dipasangkan hingga diperoleh sebuah persegi panjang dengan panjang $14 \mathrm{~cm}$ dan lebar $7 \mathrm{~cm}$. Gambar 3 menunjukkan subjek memiliki keterampilan berpikir orisinil (originality) karena mampu menemukan gagasan yang unik untuk memecahkan soal dengan cara memanfaatkan gambar sehingga diperoleh rumus yang lebih singkat (menggunakan luas setengah persegi panjang). Keterampilan memperinci (elaboration) juga terpenuhi melalui jawaban wawancara yang disampaikan subjek bahwa cara kedua dapat digunakan untuk menyelesaikan masalah yang berbeda dengan memasangkan bangun yang diarsir dan yang diarsir, sedangkan bangun yang tidak diarsir di pasangkan dengan yang tidak diarsir hingga diperoleh bentuk bangun yang utuh. Sehingga dapat disimpulkan bahwa subjek pada tingkat kemandirian belajar tinggi mampu mengembangkan gagasan baru dalam menentukan luas daerah yang diarsir atau tidak diarsir menjadi lebih menarik dengan memanfaatkan gambar sehingga menemukan penyelesaian yang lebih mudah.

\section{Jawaban Subjek dengan Tingkat Kemandirian Belajar Sedang}

Subjek dengan tingkat kemandirian belajar sedang memiliki kemampuan berpikir berpikir kreatif yang kurang, karena hanya mampu memenuhi dua indikator berpikir kreatif. Subjek hanya memenuhi indikator keterampilan kelancaran (fluency) dan keluwesan (flexibility). Sedangkan keterampilan keorisinilan (originality) dan memperinci (elaboration) belum terpenuhi.

Subjek hanya dapat memberikan satu cara penyelesaian, seperti pada gambar berikut. 


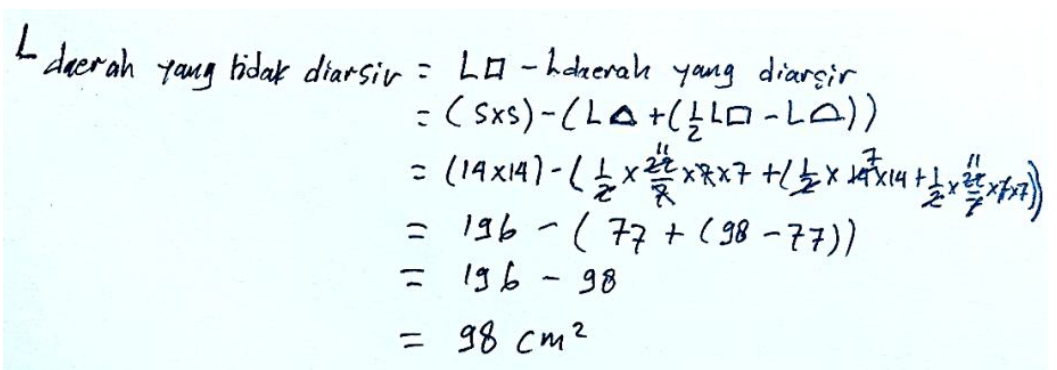

Gambar 4. Jawaban Subjek dengan Tingkat Kemandirian Belajar Sedang

Hasil pekerjaan subjek menunjukkan bahwa untuk mencari luas daerah yang tidak diarsir adalah luas persegi dikurangi luas yang diarsir. Subjek juga menjelaskan bahwa persegi dibagi menjadi 2 bagian persegi panjang. Luas daerah yang diarsir pada persegi panjang pertama (bagian atas) diperoleh dari luas persegi panjang dikurangi luas setengah lingkaran. Sedangkan pada persegi panjang kedua (bagian bawah), subjek menggabungkan 2 daerah yang diarsir menjadi setengah luas lingkaran. Subjek menyatakan tidak memiliki alternatif jawaban lain. Hal ini menunjukkan bahwa subjek memiliki keterampilan berpikir lancar (fluency) yang baik, karena mampu memberikan jawaban secara benar. Subjek kurang memiliki keterampilan berpikir luwes (flexibility) karena hanya melihat dari satu sudut pandang permasalahan yaitu menentukan daerah yang tidak diarsir dan belum mampu menemukan alternatif penyelesaian yang lain.

\section{Jawaban Subjek dengan Tingkat Kemandirian Belajar Rendah}

Subjek dengan tingkat kemandirian belajar rendah kurang memiliki kemampuan berpikir kreatif, karena hanya mampu memenuhi dua indikator berpikir kreatif. Seperti subjek dengan tingkat kemandirian belajar sedang, subjek dengan tingkat kemandirian belajar rendah hanya memenuhi indikator keterampilan kelancaran (fluency), keluwesan (flexibility).

Subjek hanya dapat memberikan satu cara penyelesaian, seperti pada gambar berikut. 


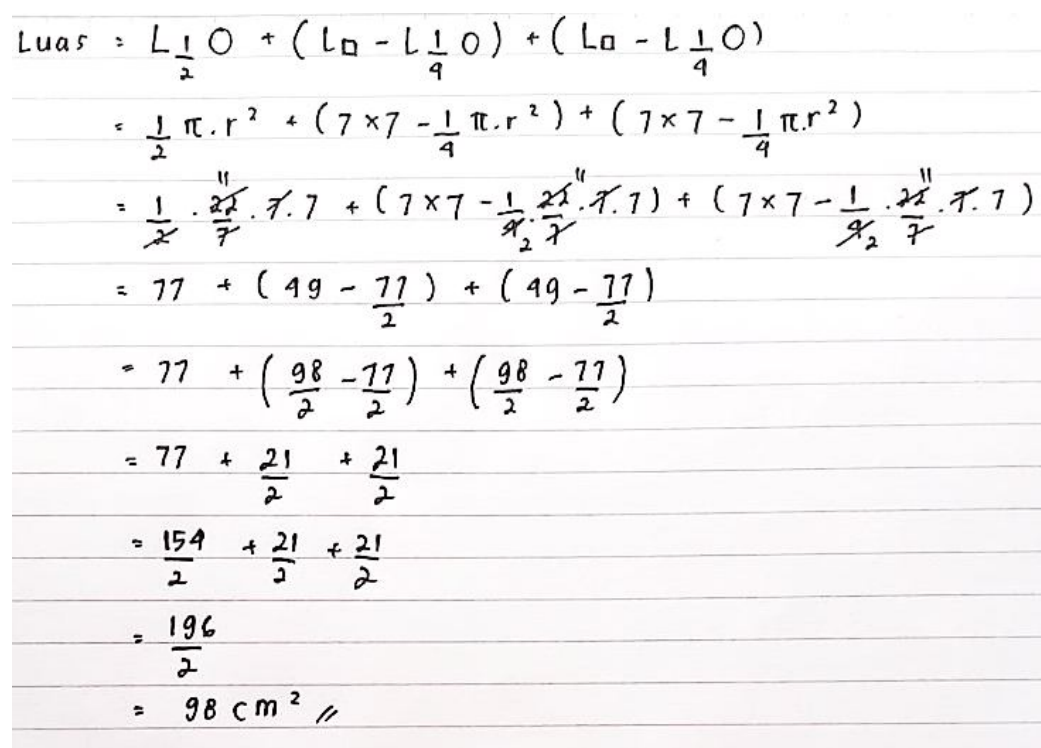

Gambar 5. Jawaban Subjek dengan Tingkat Kemandirian Belajar Rendah

Gambar 5 menunjukkan bahwa subjek dapat menjelaskan proses penentuan luas daerah yang tidak diarsir dapat dilakukan dengan membagi dua persegi menjadi persegi panjang (atas dan bawah). Persegi panjang bagian atas menunjukkan luas setengah lingkaran, sedangkan persegi panjang bagian bawah dibagi lagi menjadi dua persegi dengan panjang sisi $7 \mathrm{~cm}$. Selanjutnya subjek mengitung luas daerah yang tidak diarsir dengan cara menentukan luas persegi dikurangi luas seperempat lingkaran. Kemudian subjek menjumlahkan luas setengah lingkaran pada persegi panjang bagian atas, dengan perhitungan pada persegi panjang bawah. Subjek tidak mempunyai alternatif penyelesaian yang lain. Subjek memiliki keterampilan berpikir lancar (fluency) yang baik karena mampu memberikan jawaban secara benar. Subjek kurang memiliki keterampilan berpikir luwes (flexibility) karena hanya melihat dari satu sudut pandang permasalahan yaitu menentukan daerah yang tidak diarsir sehingga belum mampu menemukan alternatif penyelesaian yang lain. Kemampuan subjek dengan tingkat kemandirian belajar rendah dalam memberikan satu cara penyelesaian yang panjang menjadi pembeda dengan subjek dengan tingkat kemandirian belajar sedang.

Kemampuan berpikir kreatif matematis merupakan produk dari kreativitas matematika, sedangkan aktivitas kreatif merupakan suatu kegiatan dalam pembelajaran yang diarahkan untuk memunculkan atau mendorong kreativitas siswa (Purwaningrum, 2016). Pembelajaran matematika mengembangkan kemampuan 
berpikir kreatif sehingga mampu berperan meningkatkan prestasi belajar (Supardi, 2012). Dengan mengembangkan kemampuan berpikir kreatif maka siswa akan melahirkan gagasan (ide), menemukan hubungan yang saling berkaitan, membuat dan melakukan imajinasi, serta mempunyai banyak perspektif terhadap suatu hal (Mardhiyana \& Sejati, 2016).

Berdasarkan hasil-hasil yang diberikan subjek dalam tes dan wawancara diperoleh informasi bahwa subjek dengan kemandirian tinggi mampu memenuhi semua indikator berpikir kreatif, sedangkan subjek dengan kemandirian belajar sedang dan rendah hanya mampu memenuhi indikator fluency (kelancaran) dan flexibility (keluwesan). Sehingga dapat disimpulkan bahwa kemampuan berpikir kreatif subjek secara umum masih kurang. Sangat penting untuk meningkatkan kemampuan berpikir kreatif karena pada abad 21 kemampuan tersebut sangat dibutuhkan, sehingga pendidikan berperan sebagai kunci mengembangkan kreativitas siswa (Ritter, et al, 2020).

Untuk meningkatkan kemampuan berpikir kreatif peserta didik, pendidik dapat mengembangkan pembelajaran yang melibatkan pemikiran divergen dengan memberikan kesempatan yang lebih pada siswa untuk mengeksplorasi berbagai macam jawaban maupun cara penyelesaian dengan memperhatikan aspek kelancaran, keluwesan, orisinal, dan elaborasi (Hanipah, Yuliani, \& Maya, 2018). Selain menggunakan pembelajaran divergen, pendidik dapat menggunakan Pendekatan Matematika Realistik (PMR) karena dapat mengembangkan aktivitas, kreativitas dan inovasi yang dimiliki peserta didik dalam proses belajar (Sulaiman, 2018).

\section{Kesimpulan}

Pandemi Covid-19 membuat peserta didik harus belajar dari rumah secara mandiri. Peserta didik dengan kemandirian tinggi memiliki kemampuan berpikir kreatif yang baik karena mampu memenuhi indikator keterampilan fluency (kelancaran), flexibility (keluwesan), originality( orisinil), dan elaboration (memperinci). Adapun peserta didik dengan kemandirian sedang dan rendah kurang memiliki kemampuan berpikir kreatif karena hanya mampu memenuhi indikator keterampilan fluency (kelancaran), dan flexibility (keluwesan). Untuk meningkatkan kemampuan berfikir kreatif peserta didik, pendidik harus memberikan latihan soal yang didalamnya terkandung aspek-aspek berfikir kreatif dengan berbagai macam 
cara penyelesaian yaitu dengan menggunakan cara konseptual atau prosedural dan dengan menggunakan cara alternatif yang sederhana untuk membantu menyelesaikan soal sehingga mampu mengembangkan pola pikir peserta didik.

\section{Daftar Pustaka}

Agustina, I. (2020). Efektivitas Pembelajaran Matematika Secara Daring di Era Pandemi Covid-19 Terhadap Kemampuan Berpikir Kreatif. ResearchGate.

Depdiknas. (2003). Undang-Undang Republik Indonesia Nomor 20 Tahun 2003 Tentang Sistem Pendidikan Nasional. Jakarta: CV Mitra Karya.

Dinni, H. N. (2018). HOTS (High Order Thinking Skills) dan Kaitannya dengan Kemampuan Literasi Matematika. Prisma Prosiding Seminar Nasional Matematika, 1, 170-176. Semarang: Jurusan Matematika Fakultas Matematika dan Ilmu Pengetahuan Alam Universitas Negeri Semarang.

Febrianti, Y., Djahir, Y., \& Fatimah, S. (2016). Analisis Kemampuan Berpikir Kreatif Peserta Didik dengan Memanfaatkan Lingkungan pada Mata Pelajaran Ekonomi di SMA Negeri 6 Palembang.Jurnal Profit, 3(1), 121-127.

Firdausi, Y. N., Asikin, M., \& Wuryanto, W. (2018). Analisis Kemampuan Berpikir Kreatif Siswa Ditinjau dari Gaya Belajar pada Pembelajaran Model Eliciting Activities (MEA). Prisma Prosiding Seminar Nasional Matematika, 239-247. Semarang: Jurusan Matematika Fakultas Matematika dan Ilmu Pengetahuan Alam Universitas Negeri Semarang.

Hanipah, N., Yuliani, A., \& Maya, R. (2018). Analisis Kemampuan Berpikir Kreatif Matematis Siswa MTs Pada Materi Lingkaran. AKSIOMA: Jurnal Program Studi Pendidikan Matematika, 7(1), 80-86.

Jumaisyaroh, T., Napitupulu, E. E., \& Hasratuddin, H. (2015). Peningkatan Kemampuan Berpikir Kritis Matematis Dan Kemandirian Belajar Siswa Smp

Melalui Pembelajaran Berbasis Masalah. Kreano, Jurnal Matematika Kreatif-Inovatif, 5(2), 157-169. https:/ / doi.org/ 10.15294/ kreano.v5i2.3325

Kamarullah, K. (2017). Pendidikan Matematika Di Sekolah Kita. Al Khawarizmi:

Jurnal Pendidikan Dan Pembelajaran Matematika, 1(1), 21-32. https:/ / doi.org/ 10.22373/jppm.v1i1.1729

Kemdikbud. (2020). SE Mendikbud: Pelaksanaan Kebijakan Pendidikan dalam Masa Darurat Penyebaran Covid-19.

Kusumaningrum, M., \& Saefudin, A. A. (2012). Mengoptimalkan Kemampuan Berpikir Matematika melalui Pemecahan Masalah Matematika. Prosiding Kontribusi Pendidikan Matematika Dan Matematika Dalam Membangun Karakter Guru Dan Siswa, 571-580. Yogyakarta: Lumbung Pusataka Universitas Negeri Yogyakarta. 
Mardhiyana, D., \& Sejati, E. O. W. (2016). Mengembangkan Kemampuan Berpikir Kreatif dan Rasa Ingin Tahu Melalui Model Pembelajaran Berbasis Masalah. Prisma Prosiding Seminar Nasional Matematika, 672-688. Semarang: Jurusan Matematika Fakultas Matematika dan Ilmu Pengetahuan Alam Universitas Negeri Semarang.

Purwaningrum, J. P. (2016). Mengembangkan Kemampuan Berpikir Kreatif Matematis Melalui Discovery Learning Berbasis Scientific Approach. REFLEKSI EDUKATIKA, 6(2), 145-157. https:/ / doi.org/ 10.24176/ re.v6i2.613

Putri, C. A., Munzir, S., \& Abidin, Z. (2019). Kemampuan Berpikir Kreatif Matematis Siswa melalui Model Pembelajaran Brain-Based Learning. Jurnal Didaktik Matematika, 6(1), 13-28. https:/ / doi.org/ 10.24815/jdm.v6i1.9608

Ritter, S. M., Gu Id, X., Crijns, M., \& Biekens, P. (2020). Fostering students' creative thinking skills by means of a one-year creativity training program. PLoS ONE, 15(3) , 1-8. https:/ / doi.org/ 10.1371/ journal.pone.0229773

Sulaiman. (2018). Pembelajaran Matematika Realistik Tentang Luas Lingkaran Di Kelas VIII SMP. Transformasi : Jurnal Pendidikan Matematika Dan Matematika, 2(2), 26-39.

Sunhaji, S. (2014). Konsep Manajemen Kelas Dan Implikasinya Dalam Pembelajaran. Jurnal Kependidikan, 2(2), 30-46. https:/ / doi.org/ 10.24090/ jk.v2i2.551

Supardi, U. (2012). Peran Berpikir Kreatif Dalam Proses Pembelajaran Matematika. Formatif, 2(3), 248-262. https:/ / doi.org/ 10.30998/ formatif.v2i3.107

Utami, R. W., Endaryono, B. T., \& Djuhartono, T. (2020). Meningkatkan Kemampuan Berpikir Kreatif Matematis Siswa Melalui Pendekatan Open-Ended. Faktor: Jurnal Ilmiah Kependidikan, 7(1), 43-48. https:// doi.org/ 10.30998/ FJIK.V7I1.5328

Yanwar, A., \& Fadila, A. (2019). Analisis Kemampuan Berpikir Kritis Matematis: Dampak Pendekatan Saintifik ditinjau dari Kemandirian Belajar. Desimal: Jurnal Matematika, 2(1), 9-22. https:/ / doi.org/ 10.24042/ djm.v2i1.3204 